\title{
Dietary manipulation of the inflammatory response
}

\author{
BY ROBERT F. GRIMBLE \\ Institution of Human Nutrition, Medical and Biological Sciences Building, University of \\ Southampton, Southampton SO9 $3 T$ U
}

Inflammation involves a complex interaction of cells and soluble mediators. These components interact to produce a situation in which immune cells are attracted to the inflammatory locus and activated. Cytokines are among the potent soluble mediators produced during inflammation and include the interleukins (IL) 1-8, tumour necrosis factors (TNF), and interferons (Male et al. 1989). In addition to activating the immune system, a number of these molecules bring about metabolic changes in the subject which lead to the provision of nutrients for the activated immune system. The cytokines involved in this process are IL-1 and -6 and TNF- $\alpha$ and $-\beta$ (Grimble, 1990).

An inflammatory stimulus, such as invasion of tissue by bacteria, viruses or parasites, or tissue damage incurred by trauma, surgery or burns, will induce production of IL-1, IL-6 and TNF from a range of immune cells. These cells include phagocytic leukocytes, $T$ and B lymphocytes, mast cells and non-immune cells such as fibroblasts and endothelial cells (Moissec \& Ziff, 1986; Le et al. 1987; Dinarello et al. 1988; Gordon \& Galli, 1990). Once induced, IL-1 and TNF can induce each other's and IL-6 production, and IL- 6 can induce that of IL-1. Thus, a cascade of cytokines, which are capable of producing metabolic and immune effects, occurs (Old, 1987; Heinrich et al. 1990).

Inflammatory stimuli not only bring about cytokine production, free radicals are also released (Farante et al. 1988). These may enhance production of TNF and other cytokines. Clark et al. (1989) showed that experimental conditions which lead to enhanced free radical production also lead to increased TNF production, both in vitro and in vivo.

The metabolic actions of cytokines provide the mechanisms for limiting the extent and duration of cytokine production, via a number of routes (Fig. 1). These mechanisms arise from the actions of IL-1 and TNF on the hypothalamo-pituitary adrenal axis. Consequently glucocorticoids are released and have the ability to suppress cytokine production (Sherry \& Cerami, 1988). They also arise from the action of cytokines on peripheral tissue causing release of amino acids, and by direct action on hepatocytes (Perlmutter et al. 1986). Cytokines also act indirectly on liver by creating a hormonal milieu for enhancing production of acute-phase proteins. Some of these substances, such as orosomucoid, $\alpha$-2-macroglobulin and $\alpha$-1-antichymotrypsin have the ability to directly inhibit neutrophil activation and production of TNF (Costello et al. 1984; Scuderi et al. 1989). The increased production of acute-phase proteins, such as orosomucoid and caeruloplasmin (EC 1.16.3.1; CP), and of glutathione, enhance antioxidant defences and may thereby limit the stimulatory effects of free radicals released concurrently with cytokines. Acute-phase proteins are not entirely suppressive of cytokine production, since one such protein, lipopolysaccharide-binding protein, increases the sensitivity of macrophages to endotoxin and results in enhanced TNF production (Schumann et al. 1990).

The essential nature of cytokines in recovery from inflammatory situations is indicated by the poor prognosis of malnourished patients who have a reduced ability for 


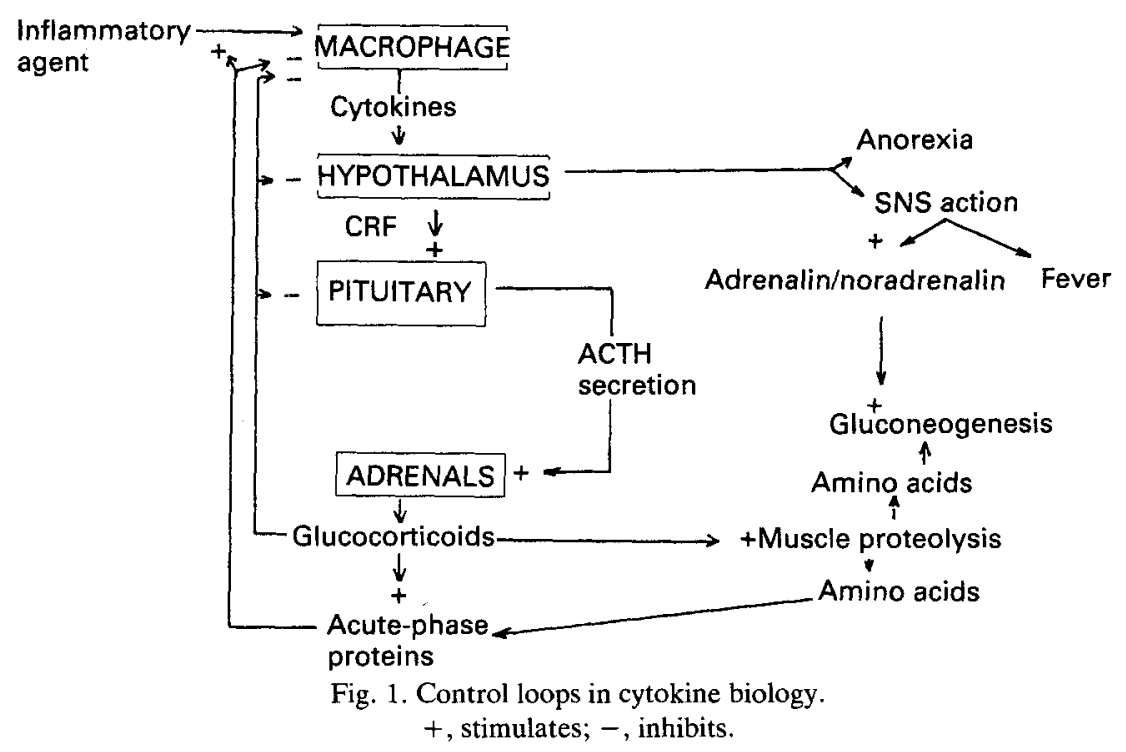

production (Keenan et al. 1982; Kauffmann et al. 1986). Paradoxically, although cytokines are central to an effective inflammatory response in combating invasion of the body, they have the potential for being lethal or tissue damaging (Beutler \& Cerami, 1986; Tracey et al. 1986; Kelley, 1990). Thus, dietary manipulation of cytokine biology can be aimed at enhancing or suppressing cytokine activity.

\section{MODULATION OF CYTOKINE BIOLOGY BY NUTRIENTS}

The cytokine-driven aspects of inflammation, with their widespread metabolic changes and dependence on secondary messengers and signalling, offer broad scope for nutritional modulation. This potential has only been partially realized. Kjeldsen-Kragh et al. (1991) found that a number of indices of inflammation were decreased when rheumatoid patients changed from an omnivore to a vegetarian diet. Improvements were noted within 1 month of changing to the diet. The precise nutrient responsible for the improvement is difficult to identify since a vegetarian diet would differ from that consumed by omnivores in terms of its fat and micronutrient content.

Efforts to modify inflammatory responses, in a clinical setting, by alterations in specific nutrients have concentrated on fats, but this class of nutrients is by no means the totality of what is theoretically possible.

\section{INFLUENCE OF FATS}

Studies on healthy individuals and patients have been limited to the influence of fish oil preparations on cytokine production, or on inflammatory symptoms in diseases in which cytokine production is likely. Endres et al. (1989) demonstrated that a 6-week period consuming $15 \mathrm{~g}$ eicosapentaenoic acid as fish oil/d was sufficient to reduce the ability of monocytes to produce IL-1- $\alpha$ and $-\beta$ and TNF- $\alpha$ and $-\beta$ in response to an endotoxin stimulus, by more than $30 \%$. The effect persisted for 10 weeks after the subjects had returned to their normal diet. Inflammatory symptoms of rheumatoid arthritis, psoriasis, 
Crohn's disease and ulcerative colitis are all ameliorated by fish oil preparations (Kremer et al. 1987; Bittiner et al. 1988; McCall et al. 1989; Solomon et al. 1990). The extent to which the amelioration is directly related to reduced cytokine production is, however, unknown.

The modulatory effects of a wide range of fats have been studied in experimental animals. Guinea-pigs experienced a smaller metabolic response to burn injury if fed on fish oil than safflower oil, and pigs and rats are protected from the effects of exposure to large doses of endotoxin by fish oil (Alexander et al. 1986; Brown et al. 1987; Murray et al. 1990). We have demonstrated that fish oil, and a range of saturated fats, including coconut oil, butter and suet, can suppress many metabolic effects of TNF in rodents. The effects influenced include increases in liver zinc content, in the rate of protein synthesis in lung and liver, and in the concentration of plasma CP (Bashir \& Grimble, 1992; Mulrooney \& Grimble, 1992a).

The modulatory effects of fats extend beyond the actions of cytokines on visceral tissue to the central nervous system. Guinea-pigs and rats fed on fish oil for 6 weeks experienced a smaller fever and lesser degree of anorexia after receiving IL-1- $\alpha$ and $-\beta$ than animals fed on diets rich in $n-6$ polyunsaturates. Coconut oil and butter were also able to ameliorate the anorectic effects of TNF- $\alpha$ (Hellerstein et al. 1989; Pomposelli et al. 1989; Mulrooney \& Grimble, 1992a). The ability of hypothalamic slices to produce prostaglandin $\mathrm{E} 2\left(\mathrm{PGE}_{2}\right)$, when incubated with endotoxin or TNF- $\alpha$ was also reduced in rats fed on diets containing coconut oil rather than maize oil (Bibby \& Grimble, 1990).

It is tempting to think that the modulatory effects of fats on actions of cytokines are mediated by alterations in prostanoid metabolism since similar modulatory effects on appetite and fever can be obtained by cyclo-oxygenase inhibitors, and fats rich in $n-3$ polyunsaturated fatty acids, such as fish oil, or poor in linoleic acid, such as butter, coconut oil or suet, may inhibit $\mathrm{PGE}_{2}$ production. However, there is substantial evidence against direct involvement of prostanoids in the actions of cytokines on liver metabolism (Sobrado et al. 1983; Johnston, 1985; Revhaug et al. 1988; Evans et al. 1989). Furthermore, although butter and coconut oil are equally poor in their linoleic acid content, the former fat is far more suppressive of the actions of TNF. One of the major differences between these saturated fats is that butter has a high content of the monounsaturated fatty acid, oleic acid. Supplementation of a diet containing coconut oil with an equivalent amount of oleic acid to that found in butter, resulted in as great a suppression of the actions of TNF as caused by butter (Table 1; Mulrooney \& Grimble, 1992b).

\section{MODULATORY EFFECTS OF PROTEIN AND AMINO ACIDS}

The studies of Keenan et al. (1982) gave the earliest indication that cytokine production is suppressed by malnutrition in patients, and that feeding protein could improve production. The suppressed ability of polymorphonuclear leucocytes (PMN) from malnourished patients to produce leucocyte endogenous mediator, was enhanced by feeding protein supplements. A number of animal studies have shown that low-protein diets impair the ability to mount a normal hepatic response to inflammatory stimuli. The increase in $\alpha$-2-macroglobulin in response to endogenous pyrogen in rabbits, and to TNF and turpentine injection in rats, was impaired by a low-protein diet (Bell \& HoffmanGoetz, 1983; Jennings \& Elia, 1990; Grimble et al. 1992). The impaired ability of protein- 
Table 1. Influence of various fats and oleic acid on the actions of recombinant human tumour necrosis factor in rats

\begin{tabular}{lccccc}
\hline & & & \multicolumn{2}{c}{ Protein synthetic rate (\%) } \\
\cline { 5 - 6 } Dietary fat* & $\begin{array}{c}\text { Appetite change } \\
(\%)\end{array}$ & $\begin{array}{c}\text { Liver zinc } \\
(\%)\end{array}$ & $\begin{array}{c}\text { Plasma CP } \\
(\%)\end{array}$ & Liver & Lung \\
\hline Maize oil & -62 & +24 & +252 & +88 & +32 \\
Fish oil & -26 & +2 & +125 & +22 & -46 \\
Coconut oil & -44 & +22 & +143 & +50 & +208 \\
Butter & -41 & +8 & +88 & -20 & +4 \\
Coconut oil & & & & +17 & -22 \\
$\quad$ oleic acid & -39 & +5 & +119 & +17 \\
\hline
\end{tabular}

$\mathrm{CP}$, caeruloplasmin (EC 1.16.3.1).

* All diets contained $100 \mathrm{~g}$ lipid $/ \mathrm{kg}$ of which $10 \mathrm{~g}$ was maize oil.

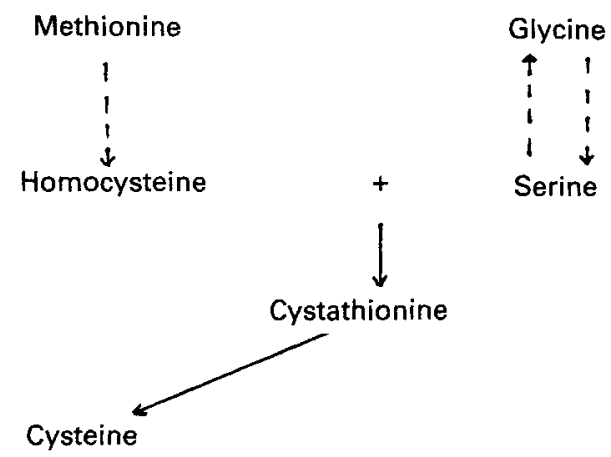

Fig. 2. Metabolic relationships between sulphur amino acids and glycine and serine.

depleted guinea-pigs to increase $\alpha-1$-acid glycoprotein in response to IL-1 was restored by infusion with an amino acid solution used for total parenteral nutrition in patients (Drabik et al. 1987).

Severe trauma and infection bring about a number of major changes in plasma amino acids. Large decreases in glycine, serine and taurine occur in these states (Askanazi et al. 1980; Jeevanandam et al. 1990; Paaw \& Davis, 1990). While these changes may be in part due to increased renal losses, they may result from enhanced utilization of a closely related group of amino acids. These are the sulphur-containing amino acids cysteine and methionine, and glycine and serine (Fig. 2). The production of many substances, that require amino acids from this group for their synthesis, is increased during inflammation. These substances include glutathione, which is comprised of glycine, glutamic acid and cysteine, metallothionein, which contains glycine, serine, cysteine and methionine, to a composite percentage of 56, and a range of acute-phase proteins which contain up to $25 \%$ of these amino acids in their structure. This hypothesis has been discussed in detail elsewhere (Grimble, 1990). The hypothesis was examined by feeding young rats one of a series of diets containing $80 \mathrm{~g}$ casein $/ \mathrm{kg}$ supplemented with isonitrogenous amounts of alanine, glycine, serine, cysteine or taurine, before injection with TNF. The concentration of protein fed was insufficient to support growth and to mount a complete hepatic response to TNF. The results (Table 2) indicate that cysteine is of prime importance in 
Table 2. Influence of supplemental amino acids in a low-protein diet on the metabolic response of rat to tumour necrosis factor

\begin{tabular}{|c|c|c|c|c|c|c|c|c|c|c|}
\hline \multirow[b]{2}{*}{$\begin{array}{l}\text { Injection . . . } \\
\text { Diet }\end{array}$} & \multicolumn{2}{|c|}{$\begin{array}{c}\text { Zinc } \\
(\mu \mathrm{g} / \mathrm{g})\end{array}$} & \multicolumn{2}{|c|}{$\begin{array}{l}\text { Liver } \\
\text { protein } \\
(\mathrm{mg} / \mathrm{g})\end{array}$} & \multicolumn{2}{|c|}{$\begin{array}{c}\text { GSH } \\
(\mathrm{mg} / \mathrm{g})\end{array}$} & \multicolumn{2}{|c|}{$\begin{array}{c}\text { Lung } \\
\text { GSH } \\
(\mathrm{mg} / \mathrm{g})\end{array}$} & \multicolumn{2}{|c|}{$\begin{array}{c}\text { Plasma } \\
\alpha-2- \\
\text { macroglobulin } \\
\text { (units) }\end{array}$} \\
\hline & $S$ & $\mathrm{~T}$ & $S$ & $\mathrm{~T}$ & S & $T$ & $S$ & $\mathrm{~T}$ & $S$ & $\mathrm{~T}$ \\
\hline $200 \mathrm{~g}$ Casein $/ \mathrm{kg}$ & 34 & 42 & 158 & 216 & 24 & 29 & 5.7 & $5 \cdot 4$ & 1.9 & 16.7 \\
\hline $80 \mathrm{~g}$ Casein: + Ala & 31 & 29 & 178 & 162 & 5 & 8 & $4 \cdot 1$ & $2 \cdot 4$ & $3 \cdot 4$ & 9.7 \\
\hline + Gly & 13 & 19 & 166 & 173 & 3 & 8 & \multicolumn{2}{|c|}{ nd } & $4 \cdot 3$ & $10 \cdot 0$ \\
\hline+ Ser & 24 & 29 & 183 & 174 & 8 & 7 & $6 \cdot 6$ & $4 \cdot 2$ & \multicolumn{2}{|c|}{ nd } \\
\hline +Cys & 22 & 31 & 148 & 211 & 19 & 25 & \multicolumn{2}{|c|}{ nd } & $3 \cdot 0$ & 7.8 \\
\hline+ Tau & 29 & 29 & 172 & 166 & 7 & 6 & $5 \cdot 5$ & $4 \cdot 1$ & \multicolumn{2}{|c|}{ nd } \\
\hline
\end{tabular}

$\mathrm{S}$ and $\mathrm{T}$, saline ( $9 \mathrm{~g}$ sodium chloride/l) and tumour necrosis factor injection respectively; GSH, glutathione; nd, not determined.

facilitating an increase in liver glutathione, $\mathrm{Zn}$ and protein content. Supplementing the diets with taurine, a major end-product of cysteine metabolism, was unable to increase cysteine availability sufficiently to have a major impact on these liver components. However, the smaller fall in lung glutathione which occurred might indicate a helpful effect of taurine on the animal's glutathione pool.

The influence of the supplemental amino acids is, however, complex since cysteine is not able to restore the response of $\alpha$-2-macroglobulin to normal. Furthermore, the influence which the supplemental amino acids had on the increase in acute-phase protein concentrations, particularly $\mathrm{CP}$, suggests that the amino acids may produce an indirect effect on hepatic metabolism, related to antioxidant status, rather than simply to provision of substrate for protein and glutathione synthesis. A highly significant negative correlation between $\mathrm{CP}$ and hepatic glutathione, and CP and lung glutathione occurred in animals treated with TNF $(r-0.54, P<0.002 ; r-0.47, P<0.02$; Figs 3 and 4$)$. Both substances are part of the animals' antioxidant defences. Animals consuming the low-protein diet supplemented with alanine have low concentrations of hepatic glutathione and are unable to increase them in response to TNF. Subsequently lung glutathione concentrations fall, and there is a compensatory increase in the CP response in an attempt to maintain antioxidant defences. Addition of cysteine to the diet restores the CP response to normal.

Thus, in a situation of malnutrition, the availability of S-amino acids may influence antioxidant defences and, thereby, effect the pattern of acute-phase protein production in an indirect manner.

The fall in plasma taurine which occurs in severe inflammatory conditions may, therefore, reflect increased S-amino acid utilization for glutathione synthesis since both substances are produced from cysteine.

\section{MODULATORY EFFECTS OF MICRONUTRIENTS}

Micronutrients are involved in the inflammatory response in a number of roles. Trace elements are present in several acute-phase proteins and other proteins which undergo 


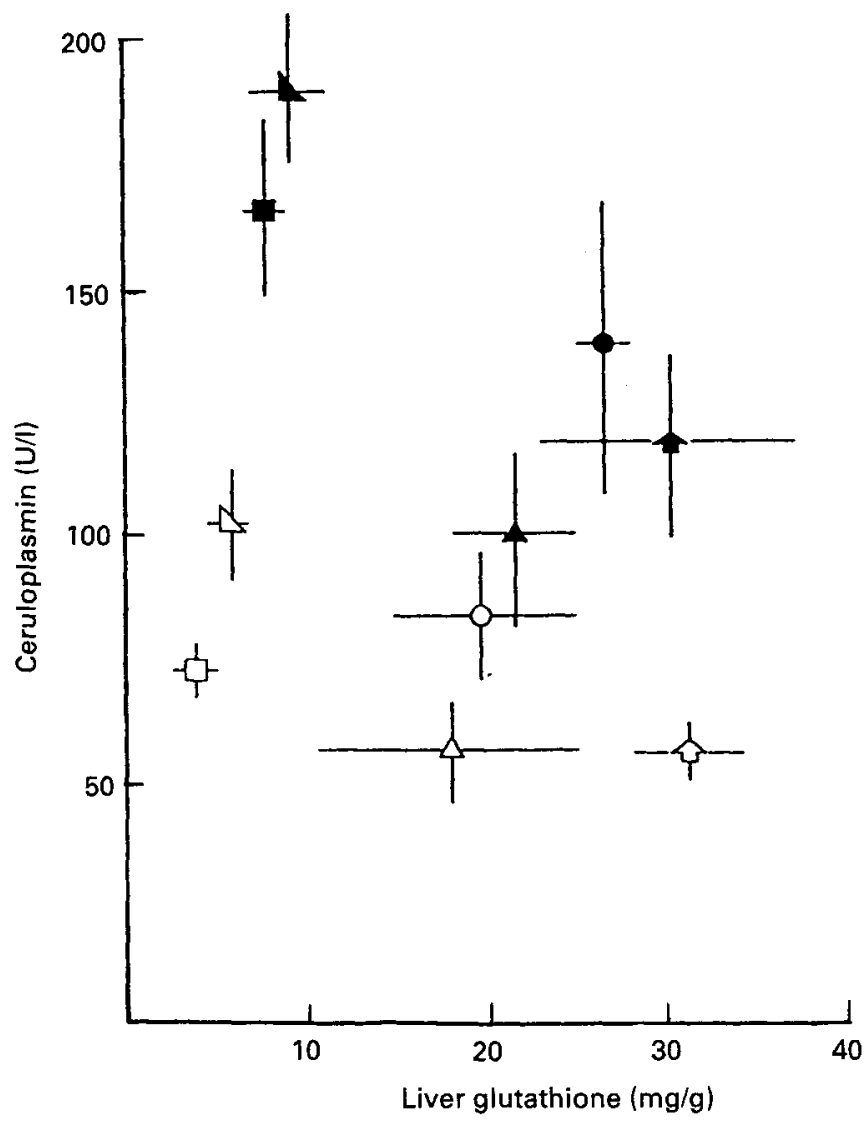

Fig. 3. Influence of glycine and cysteine on the response to tumour necrosis factor (TNF) in rats fed on an $80 \mathrm{~g}$

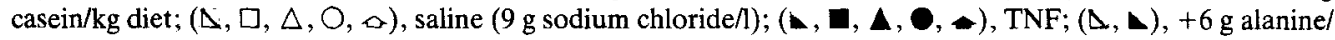
$\mathrm{kg} ;(\square, \boldsymbol{\square}),+5 \mathrm{~g}$ glycine $/ \mathrm{kg} ;(\Delta, \Delta),+$ glycine + cysteine; $(\bigcirc, \bullet),+4 \mathrm{~g}$ cysteine $/ \mathrm{kg} ; \Delta,+8 \mathrm{~g}$ cysteine $/ \mathrm{kg}$.

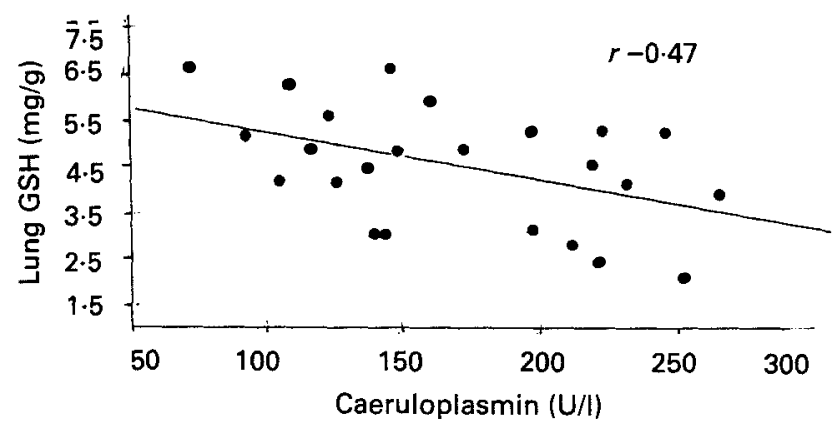

Fig. 4. Relationship of caeruloplasmin (EC 1.16.3.1) to lung glutathione (GSH) in rats given tumour necrosis factor (TNF). 
increased synthesis as a result of cytokine production. These proteins include metallothionein $(\mathrm{Zn})$, caeruloplasmin (copper), haemoglobin (iron), manganese superoxide dismutase ( $E C$ 1.15.1.1) ( $\mathrm{Mn})$ and $\mathrm{Cu}-\mathrm{Zn}$ superoxide dismutase ( $\mathrm{Cu}$ and $\mathrm{Zn}$ ).

The question of whether deficiencies in trace elements interfere with the production of these proteins during inflammation has been addressed in any detail only for $\mathrm{Cu}$ and $\mathrm{Zn}$. The ability of rats to increase plasma caeruloplasmin and $\mathrm{Cu}-\mathrm{Zn}$ superoxide dismutase in lung, in response to the dual stress of endotoxin and high oxygen concentrations, is impaired by $\mathrm{Cu}$ deficiency (Spence et al. 1986). Likewise the ability of IL-1 to increase plasma concentrations of fully functional CP is also suppressed (Barber \& Cousins, 1988). Deficiencies in $\mathrm{Zn}$ impair metallothionein synthesis in response to IL-1 and endotoxin (Huber \& Cousins, 1988).

Many of the proteins mentioned previously, are components of antioxidant defences, thus, deficient production may compromise these defences. In addition to the resulting tissue damage, enhanced cytokine production may occur as the result of the stimulatory effect of free radicals. Clarke et al. (1989) examined the effects of substances which alter free radical production, and the antioxidant environment, on TNF production by mice infected by Plasmodium vinckei. Alloxan which is a free radical generator increased TNF production fivefold, whereas butylated hydroxyanisole, a free radical scavenger, and desferrioxamine, an iron chelator, inhibited TNF production. The effect of Fe sequestration may explain why peritoneal macrophages of Fe-deficient rats have a reduced ability to produce IL-1 (Helyar \& Sherman, 1987). It may also explain why treatment of anaemic rheumatoid patients with $\mathrm{Fe}$-exacerbated inflammatory symptoms, particularly since TNF has been identified in synovial fluid of rheumatoid patients (Winyard et al. 1987).

Vitamin $\mathrm{E}$ is an important component of antioxidant defences. Oxidation of polyunsaturated fatty acids, as a result of free radical attack, leads to enhanced ethane and pentane production in respired gases. Sword et al. (1991) showed that although endotoxin injections produced no increase in ethane production in well-fed rats, production rates doubled in animals fed on a diet that was deficient in selenium and vitamin $\mathrm{E}$.

The influence of vitamin $E$ status on the response of rats to endotoxin injections was examined. The results are shown in Table 3 (Troughton \& Grimble, 1992). Animals were given diets containing no vitamin $\mathrm{E}$, a normal amount or five times the normal amount for 3 weeks before injection. Histological examination of the lungs indicated infiltration of the lungs by immune cells which was more severe in the deficient animals than in those receiving the normal or enhanced amount of vitamin $E$. The deficient animals experienced the largest anorexic response to endotoxin and the largest increase in orosomucoid. These findings may indicate increased cytokine production in animals whose antioxidant defences have been compromised by lack of vitamin $E$.

Vitamin A status may also influence cytokine production, although a possible mechanism by which it may do so is unclear. Macrophages from Indian children receiving a supplement of $100000 \mathrm{IU}$ produced nine times as much as macrophages of children not receiving supplementation (Bhaskaram et al. 1989). It is not clear whether the observed effects of the vitamin are of pharmacological or nutritional significance since the supplementation dose is by necessity much greater than habitual intakes. Indeed, Moroguchi et al. (1985) demonstrated that mice given an amount of vitamin $\mathrm{A}$ that was sixteen times the normal intake resulted in a doubled IL-1 production by peritoneal 
Table 3. Influence of vitamin E status of rats on the response to Escherichia coli endotoxin

\begin{tabular}{|c|c|c|c|c|c|c|}
\hline \multirow{2}{*}{$\begin{array}{l}\text { Dietary vitamin } \mathrm{E}(\mathrm{mg} / \mathrm{kg}) \\
\text { Injection . . }\end{array}$} & \multicolumn{2}{|c|}{0} & \multicolumn{2}{|c|}{50} & \multicolumn{2}{|c|}{250} \\
\hline & $S$ & $\mathrm{E}$ & $\mathbf{S}$ & $\mathrm{E}$ & $\mathrm{S}$ & $\mathrm{E}$ \\
\hline \multicolumn{7}{|l|}{ Food intake } \\
\hline (g/24 h post injection) & 23 & 3 & 27 & 13 & 24 & 17 \\
\hline Liver wt ( $\mathrm{g} / \mathrm{kg}$ body-wt) & 40 & 51 & 37 & 51 & 41 & 53 \\
\hline \multicolumn{7}{|l|}{ Plasma $\alpha$-1-acid } \\
\hline glycoprotein (units/ml) & 22 & 256 & 14 & 157 & 18 & 163 \\
\hline Plasma vitamin $\mathrm{E}(\mathrm{ng} / \mathrm{ml})$ & & & & & & \\
\hline Erythrocyte vitamin $E(\mathrm{ng} / \mathrm{ml})$ & & & & & & \\
\hline
\end{tabular}

$\mathrm{S}$ and $\mathrm{E}$, saline ( $9 \mathrm{~g}$ sodium chloride/l) and endotoxin injection respectively.

macrophages, in response to endotoxin, in vitro. The vitamin may have an as yet undefined role in cytokine production since Bowman et al. (1990) found decreased interferon production and natural killer cell activity in vitamin A-deficient rats.

\section{REFERENCES}

Alexander, J. W., Saito, H., Ogle, C. K. \& Trocki, O. (1986). The importance of lipid type in the diet after burn injury. Annals of Surgery 204, 1-8.

Askanazi, J., Carpenter, Y. A., Michelsen, C. B., Elwyn, D. H., Furst, P., Kantrowitz, L. R., Gump, F. E. \&

Kinney, J. M. (1980). Muscle and plasma amino acids following injury: Influence of intercurrent infection. Annals of Surgery 188, 797-803.

Barber, E. F. \& Cousins, R. J. (1988). Interleukin-1 stimulated induction of ceruloplasmin synthesis in normal and copper deficient rats. Journal of Nutrition 118, 375-381.

Bashir, S. \& Grimble, R. F. (1992). Effects of tumour necrosis factor- $\alpha$ on lungs and liver in mice are modified by fats of varying saturated, monounsaturated and polyunsaturated fatty acid content. Proceedings of the Nutrition Society 51, 88A.

Bell, R. \& Hoffman-Goetz, L. (1983). Effect of protein deficiency on endogenous pyrogen-mediated acute phase protein response. Canadian Journal of Physiology and Pharmacology 61, 376-387.

Beutler, B. \& Cerami, A. (1986). Tumour necrosis factor as two sides of the same biological coin. Nature 320, 584-588.

Bhaskaram, P., Sharada, K., Sivakumar, B., Rao, K. V. \& Nair, M. (1989). Effect of iron and vitamin A deficiencies on macrophage function in children. Nutrition Reviews $9,35-45$.

Bibby, D. C. \& Grimble, R. F. (1990). Tumour necrosis factor $\alpha$ and endotoxin induce less prostaglandin $E_{2}$ production from hypothalami of rats fed coconut oil than from hypothalami of rats fed maize oil. Clinical Science 79, 657-662.

Bittiner, S. B., Tucker, W. F. G., Cartwright, I. \& Bleeker, S. S. (1988). A double-blind, randomised, placebo-controlled trial of fish oil in psoriasis. Lancet $\mathbf{i}, 378-380$.

Bowman, T. A., Goonewardene, I. M., Pasatiempo, A. M. G., Ross, A. C. \& Taylor, C. E. (1990). Vitamin A deficiency decreases natural killer cell activity and interferon production in rats. Journal of Nutrition 120 , 1264-1273.

Brown, G., Hunt, V., Wan, J. \& Grimble, R. F. (1987). The differing response of zinc and protein metabolism to $E$. coli endotoxin in rats fed diets containing maize, coconut and fish oils. Proceedings of the Nutrition Society 46, 36A.

Clark, I. A., Cowden, W. B. \& Chaudhri, G. (1989). Possible role of oxidants through tumour necrosis factor in malarial anaemia. Malaria and the Red Cell 2, 73-82.

Costello, M. J., Gewurz, H. \& Siegel, J. N. (1984). Inhibition of neutrophil activation by $\alpha$-acid glycoprotein. Clinical and Experimental Immunology 55, 465-472.

Dinarello, C. A. (1986). Multiple biological properties of recombinant human interleukin 1 (beta). Immunobiology 172, 301-315.

Dinarello, C. A. (1988). Biology of Interferon 1. FASEB Journal 2, 108-115. 
Drabik, M. D., Schure, F. C., Mok, K. T., Moldawer, L. L., Dinarello, C. A., Blackburn, G. L. \& Bistrian, B. R. (1987). Effect of protein depletion and short term parenteral refeeding on the host response to interleukin-1 administration. Journal of Laboratory and Clinical Medicine 109, 509-519.

Endres, S., Ghorbani, R., Kelley, V. E., Georgilis, K., Lannemann, G., Van der Meer, J. W. M., Cannon, J. G., Rogers, T. S., Klempner, M. S., Weber, P. C., Schaeffer, E. J., Wolff, S. M. \& Dinarello, C. A. (1989). The effect of dietary supplementation with $n-3$ polyunsaturated fatty acids on the synthesis of IL1 and TNF $\alpha$ by mononuclear cells. New England Journal of Medicine 320, 266-271.

Evans, D., Jacobs, D. O., Revhaug, A. \& Wilmore, D. (1989). The effects of tumour necrosis factor and their selective inhibition by ibuprofen. Annals of Surgery 209, 312-321.

Farante, A., Nandoskar, M., Walz, A., Goh, D. H. B. \& Kowanko, I. C. (1988). Effects of tumour necrosis factor alpha and interleukin 1 alpha and beta on human neutrophil migration, respiratory burst and degranulation. International Archives of Allergy and Applied Immunology 86, 82-91.

Gordon, J. R. \& Galli, S. J. (1990). Mast cells as a source of both preformed and immunologically inducible TNF $\alpha$ cachectin. Nature 346, 274-276.

Grimble, R. F. (1990). Nutrition and cytokine action. Nutrition Research Reviews 3, 193-210.

Grimble, R. F., Jackson, A. A., Persaud, C., Wride, M. J., Delers, F. \& Engler, R. (1992). Cysteine and glycine supplementation modulate the metabolic response to tumour necrosis factor $\alpha$ in rats fed a low protein diet. American Journal of Clinical Nutrition (In the Press).

Heinrich, P. C., Castell, J. V. \& Anders, P. (1990). Interleukin 6 and the acute phase response. Biochemical Journal 265, 621-636.

Hellerstein, M. K., Meydani, S. N., Metdani, M., Wu, K. \& Dinarello, C. A. (1989). Interleukin-1-induced anorexia in the rat. Influence of prostaglandins. Journal of Clinical Investigation 84, 228-235.

Helyar, L. \& Sherman, A. R. (1987). Iron deficiency and interleukin 1 production by rat leukocytes. American Journal of Clinical Nutrition 46, 346-352.

Huber, K. L. \& Cousins, R. J. (1988). Maternal zinc deprivation and interleukin-1 influence metallothionein gene expression and zinc metabolism of rats. Journal of Nutrition 118, 1570-1576.

Jeevanandam, M., Young, D. H., Ramais, L. \& Schiller, W. R. (1990). Effect of major trauma on plasma free amino acid concentrations in geriatric patients. American Journal of Clinical Nutrition 51, 1040-1050.

Jennings, G. \& Elia, M. (1990). Effect of protein deficiency on circulating protein concentrations during the acute phase response to injury. Proceedings of the Nutrition Society 49, 159A.

Johnston, P. V. (1985). Dietary fat, eicosanoids and immunity. Advances in Lipid Research 21, $102-139$.

Kauffman, C. A., Jones, P. G. \& Kluger, M. J. (1986). Fever and malnutrition: endogenous pyrogen/ interleukin-1 in malnourished patients. American Journal of Clinical Nutrition 44, 449-452.

Keenan, R. A., Moldawer, L. L., Yang, R. D., Kawamura, I., Blackburn, G. L. \& Bistrian, B. (1982). An altered response by peripheral leukocytes to synthesise or release leukocyte endogenous mediator in critically ill protein-malnourished patients. Journal of Laboratory and Clinical Medicine 100, 844-857.

Kelley, J. (1990). Cytokines and the lung. American Review of Respiratory Disease 141, 765-788.

Kjeldsen-Kragh, J., Haugen, M., Borchgrevink, C. F., Laerum, E., Eek, M., Mowinkel, P., Hovi, K. \& Forre, O. (1991). Controlled trial of fasting and one-year vegetarian diet in rheumatoid arthritis. Lancet 339, 899-902.

Kremer, J. M., Jubiz, W., Michalek, A., Rynes, R. I., Bartholomew, L. E., Bigaouette, J., Timchalk, M., Beeler, D. \& Lininger, L. (1987). Fish oil fatty acid supplementation in active rheumatoid arthritis: a double-blinded, placebo-controlled, crossover trial. Annals of Internal Medicine 106, 497-502.

Le, J., Weinstein, D., Gubler, U. \& Vilcek, J. (1987). Induction of membrane associated interleukin 1 by tumor necrosis factor in human fibroblasts. Journal of Immunology 138, 2137-2142.

McCall, T. B., O'Leary, D., Bloomfield, J. \& O'Morain, C. A. (1989). Therapeutic potential of fish oil in the treatment of ulcerative colitis. Alimentary Pharmacology and Therapeutics 3, 415-424.

Male, D., Roitt, I., Rook, G., Lydyard, P. \& Grossi, C. (1989). Adaptive and innate immunity. In Immunology, pp. 1-10 [I. Roitt, J. Brostoff and D. Male, editors]. Edinburgh, London and Melbourne: Churchill Livingstone.

Moissec, P. \& Ziff, M. (1986). Immune interferon enhances the production of interleukin 1 by human endothelial cells stimulated by lipopolysaccharide. Journal of Immunology 137, 2848-2852.

Moroguchi, S., Werner, C. \& Watson, R. R. (1985). High dietary vitamin A (retinyl palmitate) and cellular immune functions in mice. Immunology 56, 169-177.

Mulrooney, H. M. \& Grimble, R. F. (1992a). The influence of butter, and corn, coconut and fish oils on the effects of tumour necrosis factor $\alpha$ in rats. Clinical Science (In the Press). 
Mulrooney, H. M. \& Grimble, R. F. (1992b). Oleic acid as a determinant of the differences between the suppressive effects of coconut oil and butter on responses to tumour necrosis factor- $\alpha$ in rats. Proceedings of the Nutrition Society 51, 89A.

Murray, J., Svingen, B. A. \& Yaksh, T. L. (1990). Response to bacteraemia in pigs prefed on an $\omega 3$ fatty acid diet. Journal of Parenteral and Enteral Nutrition 13, Suppl. 4, 1.

Old, L. F. (1987). Polypeptide mediator network. Nature 326, 330-331.

Paaw, J. D. \& Davis, A. T. (1990). Taurine concentrations in serum of critically injured patients and age- and sex-matched healthy control subjects. American Journal of Clinical Nutrition 49, 814-822.

Perlmutter, D. H., Dinarello, C. A., Punsal, P. I. \& Colten, H. R. (1986). Cachectin/tumor necrosis factor regulates hepatic acute phase gene expression. Journal of Clinical Investigation 78, 1349-1354.

Pomposelli, J. J., Mascioli, E. A., Bistrian, B. R., Lopez, S. M. \& Blackburn, G. L. (1989). Attenuation of the febrile response in guinea pigs by fish oil enriched diets. Journal of Parenteral and Enteral Nutrition 13, 136-140.

Revhaug, A., Michie, H. R., Manson, T., Walters, J. M., Dinarello, C. A., Wolff, S. M. \& Wilmore, D. W. (1988). Inhibition of cyclooxygenase attenuates the metabolic response to endotoxin in humans. Archives of Surgery 123, 162-170.

Schumann, R. R., Leang, S. R. \& Flaggs, G. W. (1990). Structure and function of lipopolysaccharide binding protein. Science 249, 1429-1431.

Scuderi, P., Dorr, R. T., Liddil, J. D., Finley, P. R., Meltzer, P., Raitano, A. B. \& Rybski, A. B. (1989). Alpha-globulins suppress human leukocyte tumour necrosis factor secretion. European Journal of Immunology 19, 939-942.

Sherry, B. \& Cerami, A. (1988). Cachectin/tumor necrosis factor exerts endocrine, paracrine and autocrine control of inflammatory responses. Journal of Cell Biology 107, 1269-1277.

Sobrado, J., Moldawer, L. L., Bistrian, B. A., Dinarello, C. A. \& Blackburn, G. L. (1983). Effect of ibuprofen on fever and metabolic changes induced by continuous infusion of leukocytic pyrogen (interleukin 1) and endotoxin. Infection and Immunity 42, 997-1005.

Solomon, P., Kornbluth, A. A. \& Janowitz, H. D. (1990). Treatment of ulcerative colitis with fish oil $n-3-\omega$ fatty acid: An open trial. Journal of Clinical Gastroenterology 12, 157-161.

Spence, T. H., Jenkinson, S. G., Johnston, K. H., Collins, J. F. \& Lawrence, R. A. (1986). Effects of bacterial endotoxin in protecting copper-deficient rats from hyperoxia. Journal of Applied Physiology 61, 982-987.

Sword, J. T., Pope, A. L. \& Hoekstra, W. G. (1991). Endotoxin and lipid peroxidation in selenium and vitamin E-deficient rats. Journal of Nutrition 121, 251-257.

Tracey, K. J., Beutler, B., Lowry, S. F., Merryweather, J., Wrepe, S., Milsark, I. W., Hariri, R. J., Fahey, T. J., Alejandro, Z. C., Albert, J. A., Shires, T. \& Cerami, A. (1986). Shock and tissue injury induced by recombinant human cachectin. Science 234, 4709-474.

Troughton, K. \& Grimble, R. F. (1992). Vitamin E status modulates the inflammatory response to endotoxin in rats. Proceedings of the Nutrition Society 51 (In the Press).

Winyard, P. G., Blake, D. R., Chirico, S., Gutteridge, J. M. C. \& Lunec, J. (1987). Mechanism of exacerbation of rheumatoid arthritis by total-dose iron-dextran infusion: in vivo demonstration of iron-promoted oxidant stress. Lancet i, 69-72. 